УДК: $368.01 / .022$

Оригинални научни рад
ПОСЛОВНА ЕКОНОМИЈА

BUSINESS ECONOMICS

Година IX

Број II

стр. 129-154

\title{
др Миро Сокић ${ }^{1}$
}

Компанија Дунав осигурање а.д.о.

др Љиљана Јеремић² редовни професор

Универзитет Сингидунум

др Драгица Јанковић ${ }^{3}$

Компанија Дунав осигурање а.д.о.

\section{TРЖИШНИ РИЗИК И VАR МОДЕЛ КОД ИНВЕСТИРАҢА СРЕДСТАВА ОСИГУРАВАЈУЋИХ КОМПАНИЈА}

\begin{abstract}
САЖЕТАК: Раст реалног бруто домаћег производа и економски опоравак наше земље, иако успорен, представља неминовност у годинама које долазе. Исти ће се позитивно одразити на јачање Сектора осигурања у Републици Србији чија је вредност наставила позитиван тренд, и у 2014. години износи 574 милиона евра. Порашће наравно и просечна премија у неживотном, а поготово у сфери животног осигурања. Простора за инвестициону активност биће далеко више, а колико осигуравајуће куће буду успешне у процесу оптимизације депоновања и улагања слободних финансијских средстава на финансијском тржишту, умногоме ће зависити и њихова позиционираност и опстанак у будућности. Када се нађу на финансијском тржишту, осигуравачи се сусрећу пре свега са тржишним ризиком. Један од најбољих алата за управљање истим јесте примена VaR (Value-at-Risk) модела или модела ризичне вредности. Управљање тржишним ризиком
\end{abstract}

1 miro.sokic@dunav.com

2 ljjeremic@singidunum.ac.rs

3rjankovic1@dunav.com 
путем VaR модела врши се код портфолио инвестирања и представља приказ максималног могућег губитка који неће бити премашен у одређеном временском периоду и са одређеним нивоом поверења.

$\mathrm{VaR}$ модел биће афирмисан кроз практичан пример израчунавања Маргиналног, Инкременталног и Компонентног VaR-a, а његова предност се огледа у чињеници да омогућава поређење ризичности различитих финансијских инструмената и портфолиа. Акценат ће бити стављен на квантитативну методу код доношења управљачких одлука везаних за инвестирање средстава осигуравајућих компанија, али и неопходност уважавања резултата квалитативне анализе.

Кључне речи: тржишни ризик, VaR модел, Маргинални, Компонентни и Инкрементални VaR, портфолио инвестирање, квантитативна и квалитативна анализа...

\section{УПРАВЉАЊЕ ТРЖИШНИМ РИЗИКОМ ПУТЕМ VАR МОДЕЛА}

Финансијске институције су развиле VaR (Value-at-Risk) модел као општу меру економског губитка који може одговарати ризику појединачних позиција и укупном ризику портфолиа. Највећим делом мерење ризика на основу VaR методологије користе финансијске институције у менаџменту капитала, портфолиа и финансијског извештавања. VaR метода је настала када је Денис Ведерстон као председавајући J. П. Моргана захтевао да му се свакодневно по завршетку радног дана поднесе извештај у форми једне странице, који ће сублимирати изложеност компаније кретањима на тржишту и пружити јасну слику процене потенцијалних губитака у наредна 24 часа. Та је процена добила назив „вредност под ризиком“ Value-at-Risk ( $\mathrm{VaR})$.

$\mathrm{VaR}$ се дефинише као максимални очекивани губитак током датог временског периода посматрања, под нормалним тржишним условима, уз дефинисани ниво поузданости. ${ }^{4}$ Примамљивост VaR решења постоји из разлога што оно функционише на више нивоа, од посматрања појединачних позиција до нивоа портфолиа користећи појединачне инструменте или организационе делове као позиције у портфолиу. VaR je постао уни-

4 Dowd Kevin, „Beyond value at risk: The new science of risk management“, John Wiley\&Sons Ltd, West Sussex, England, 1998, str. 39. 
верзални начин саопштавања позиција ризика, како унутар финансијских институција (банке, осигуравајуће компаније, инвестициони фондови), тако и изван њих (међу аналитичарима, надзорним органима, рејтинг агенцијама и акционарима).

VaR представља максимални могући губитак који неће бити премашен у одређеном временском периоду и са одређеним нивоом поверења.

Уколико је једнодневни VaR са нивоом поверења 99\% од 10 милиона динара, то значи да са 99\% вероватноће сутрашњи губитак неће бити већи од 10 милиона динара. Ниво поверења означава вероватноћу да максимални могући губитак неће прећи одређени лимит. Већа вероватноћа значиће наравно и већи максимални губитак.

Приликом одређивања резерви капитала осигуравајуће компаније, пожељно је користити конзервативнији приступ процене (99\%) што је у складу и са новом директивом Солвентност II, док је за постављање лимита могуће применити и нижи ниво поверења (95\%). VaR анализа на приступачан начин сумира ризик од губитака који потичу од варијација фактора тржишног ризика и као таква има две основне карактеристике:

Прва говори да он представља стандардну меру ризика кроз различите позиције изложености и факторе ризика. Такође, омогућава мерење ризика повезаног са позицијом у хартијама од вредности са фиксним приносом на начин да је упоредив са мером ризика повезаним са акцијским или другим пласманима.

- Друга карактеристика узима у обзир корелације између различитих фактора ризика.

- $\quad \mathrm{VaR}$ се може користити у различите сврхе:

- Информационо извештавање,

- Алокацију ресурса,

- Процену успешности пословања.

Пошто VaR извештава о максималној могућој суми која се може изгубити, може се користити за дефинисање интерне алокације капитала. Користи се за дефинисање потреба за капиталом на нивоу компаније, али такође и низ хијарархију до нивоа индивидуалних инвестиционих одлука.

5 Jorrion Phillipe, „Value at Risk: The New Benchmark for Controlling Market Risk“, Mc GrawHill, 2001, str. 263. 
Предност VaR-a је да ствара заједнички именилац са којим се може вршити поређење ризичних активности на тржиштима.

VaR ce може користити за процену различитих инвестиционих могућности пре доношења одлуке, као и за процену продуктивности пословних делова. Вероватно највећа корист од VaR-a лежи у чињеници да он намеће структурну методологију за критичко размишљање о ризику. Финансијске институције које уведу систем базиран на VaR методологији морају да ускладе организацију фирме, тако да је сам процес увођења VaRa значајан за здраво управљање ризиком у финансијским институцијама.

Предности VaR модела огледају се следећим чињеницама:

1. Пружа вишем менаџменту основу за бољу информисаност и управљање ризиком;

2. Применљив је на различите врсте финансијских инструмената (портфолиа) и омогућава поређење ризичности истих;

3. Води настанку нових система контроле који смањују могућност превара и људских грешака;

4. Пружа конзистентан, интегрални приступ ризицима што води већој транспарентности ризика друштва за осигурање;

5. Омогућава компанијама да одговоре прикладно на регулационе захтеве, посебно у погледу адекватности капитала;

6. Води интегралном третману ризика пошто узима у обзир све врсте финансијских ризика.

Када говоримо о недостацима $\mathrm{VaR}$ модела треба имати у виду:

1. Сви VaR модели су ограничени претпоставком да се будући ризици могу антиципирати на основу историјске дистрибуције приноса. Такво закључивање може, али и не мора имати реалну основу пошто увек постоји могућност велике промене на тржишту.

2. Постоји такође могућност да су временске серије неопходне као инпути ограничене у погледу расположивости и поузданости података, те је стога VaR модел који у суштини има квантитативан карактер, неопходно допунити квалитативном анализом.

6 Бранко Урошевић, „Value at Risk“, Економски факултет Београд, Београд, 2008, стр. 76. 


\section{Квантитативна примена историјског сценарија за израчунавање VaR-a на портфолио од три хартије од вредности}

Примена историјског сценарија захтева дуже временске серије података (веће временске узорке), да би се могли извући мериторни закључци. Историјски сценарио се најчешће користи у случају пуне ликвидности тржишта хартија од вредности. Једноставан је за примену јер не захтева процену матрице варијансе и коваријансе, него се директно ослања на кретање цена хартија од вредности, односно укупне вредности портфолиа. У вези са претходном анализом поставља се питање на који начин аналитички доћи до вероватноће за поједине сценарије? Прво решење полази од логичне идеје "да се историја понавља" што би значило да ће приноси у будућности имати исту или сличну расподелу, као што је то био случај у претходном периоду. Историјски сценарио, како се назива овакав начин предвиђања приноса, наравно има озбиљних недостатака - варијације приноса из прошлости се често не понављају у будућности, посебно у периодима великих рецесија и економске нестабилности. Предвиђања у погледу расподеле приноса, на основу података из прошлости, показују често велике разлике у односу на стварна кретања, без обзира на величину узорка (број коришћених података). Кретање цене приносне стопе у времену има одређену расподелу, коју је врло тешко апроксимирати неким теоретским моделом, тако да би се некој вредности приносне стопе могла приписати одговарајућа вероватноћа. Упрошћена претпоставка је да све приказане стопе приноса у временској серији имају исту, константну вероватноћу. У том случају средњу (очекивану) вредност приносне стопе $\mathrm{E}(\mathrm{p})$ можемо изразити као;

$$
E(p)=\bar{p}=\sum_{\tau=1}^{H} \frac{p_{\tau}}{H}
$$

где је рт приносна стопа у тренутку т, при чему т узима вредности $1,2,3, \ldots, \mathrm{H}-1, \mathrm{H}$, а Н представља укупан број опсервација приносне стопе у одређеном времену. За груписане податке са означеном фреквенцијом (број опсервација са истом вредношћу) очекивану вредност можемо изразити као;

$$
E(p)=\bar{p}=\sum_{u=1}^{H} \frac{\Phi_{n} p_{u}}{H}
$$


$\phi_{\text {т }}$ фреквенција стопе рт у расподели приноса при чему је;

$$
\sum_{1}^{\mathrm{B}} \phi_{\mathrm{T}}=\mathrm{H}
$$

Мера одступања неке величине од средње вредности је варијанса, односно стандардна девијација. Варијанса, односно стандардна девијација представља одступање случајне променљиве приноса од њене средње вредности изражено у истим јединицама мере, и може се изразити као:?

$$
\operatorname{Bap}(\mathrm{p})=\sigma^{2}=\sum_{\mathrm{\tau}=1}^{\mathrm{H}} \frac{\left(\mathrm{p}_{\mathrm{\tau}}-\overline{\mathrm{p}}\right)^{2}}{\mathrm{H}-1}, \text { односно } \sigma=\sqrt{\sum_{\mathrm{T}=1}^{\mathrm{H}} \frac{\left(\mathrm{p}_{\mathrm{\tau}}-\overline{\mathrm{p}}\right)^{2}}{\mathrm{H}-1}}
$$

и добија се као збир квадрата одступања појединачних приносних стопа од средње вредности $\overline{\mathrm{p}}$ са бројем опсервација н умањеним за 1. Израз $\mathrm{H}-1$ се узима због умањења за један степен слободе, односно оцене једног додатног параметра у имениоцу - средње вредности и на тај начин добијамо ткз. непристрасну оцену основног скупа, у овом случају скупа приносних стопа. За потребе анализе која следи коришћени су подаци о кретању цена акција АИК Банке Ниш ${ }^{8}$ и обвезница старе девизне штедње А2013 у периоду од пет календарских година (од 01. 01. 2006. до 31. 12. 2010. године). У наведеном периоду се трговало овим акцијама и обвезницама 1258 дана или скоро сваког радног дана Берзе. Ради веће прегледности извршено је груписање по вредности почев од најниже до највише приносне стопе у поменутом периоду, коришћењем једнаког размака и везивањем фреквенција за одговарајућу вредност стопе приноса. Стопа приноса рп је рачуната у процентима као;

$$
\mathrm{p}_{\mathrm{n}}=\frac{\Pi_{\tau}-\Pi_{\tau-1}}{\Pi_{\tau-1}}
$$

при чему је;

Пт - цена акције (обвезнице) на дан т,

7 Elton, E., Gruber, M. „Modern portfolio Theory and Investment Analysis“ (Модерна портфолио теорија и инвестициона анализа), John WileyひSons Inc. United States of America, 2001, str. 59.

8 Акције АИК Банке су изабране јер су биле ликвидне у посматраном периоду, тј. предмет трговине од 01.01.2006. до 31.12.2010. године (најмање 70\% времена или 881 дан). 
Пт-1 - цена акције (обвезнице) на дан т-1 (претходни дан),

За анализу која следи узели смо 200 акција АИК банке по цени од 3323 динара и 100 обвезница старе девизне штедње по цени од 9558,14 динара која је била на крају 2010. године. Дневне приносне стопе за цео период од 2006 до 2010. године се добијају коришћењем следеће формуле:

$$
\mathrm{p}_{п}(\mathrm{~T})=\mathrm{Wa} \mathrm{pa}(\mathrm{T})+\text { Wo } \mathrm{po}_{\text {o }}(\mathrm{T})
$$

где ознаке имају следеће значење:

рп(т) - дневна стопа приноса инвестиционог портфолиа, на бази константног учешћа две позиције хартија од вредности у портфолиу, при чему тє 1,2,3, ...., 1258 (дневне стопе принос за пет година, од 01.01.2006. до 31.12.2010., укупно 1258 дана котирања ХоВ на берзи),

Wa - учешће вредности акција АИК банке у портфолиу на дан 31.12.2010. године - ово учешће износи 0,41 и добија се;

$$
\mathrm{W}_{\mathrm{a}}=\frac{200 * 3323}{200 * 3323+100 * 9.558,14}=0,41
$$

w0 - учешће вредности обвезница А2013 у портфолиу на дан 31.12.2010. године - ово учешће износи 0,59 и добија се;

$$
W_{o}=\frac{100 * 9.558,14}{200 * 3323+100 * 9.558,14}=0,59
$$

\section{Очигледно је да је wa + wo $=1$}

ра (т) - дневне стопе приноса акција АИК банке за тє 1,2,3, ...., 1258 (за период од 01.01.2006. до 31.12.2010., укупно 1258 дана котирања акција АИК банке на берзи),

ро (т) - дневне стопе приноса обвезница А 2013 за тє 1,2,3, ..., 1258 (за период од 01.01.2006. до 31.12.2010., укупно 1258 дана котирања обвезница на берзи).

Серија података о стопама приноса за период од 2006. до 2010. године добија се полазећи од константног учешћа поменуте две позиције у укупној вредности портфолиа утврђеног на дан 31.12.2010. године. 
Табела бр. 1 - Кретане стопа приноса на портфболио (200 акиија АИК Ниш и 100 обвезнииа А2013) 01.01.2006 до 31.12.2010. године

\begin{tabular}{|c|c|c|c|c|c|}
\hline $\begin{array}{c}\text { Стопа } \\
\text { приноса рп } \\
\text { у \% }\end{array}$ & Фреквенција & рп ф & $\phi\left(\mathrm{p} \Pi^{-} \overline{\boldsymbol{r}_{\boldsymbol{p}}}\right) 2$ & $\begin{array}{c}\text { Кумулатив } \\
\text { аи\% }\end{array}$ & $\begin{array}{l}\text { Инверзни } \\
\text { кумулатив } \\
(100-\text { аи) \% }\end{array}$ \\
\hline$-6,90$ & 1 & $-6,90$ & 48,33 & $0,08 \%$ & $99,92 \%$ \\
\hline$-6,30$ & 0 & 0,00 & 0,00 & $0,08 \%$ & $99,92 \%$ \\
\hline$-5,70$ & 1 & $-5,70$ & 33,04 & $0,16 \%$ & $99,84 \%$ \\
\hline$-5,09$ & 3 & $-15,28$ & 79,44 & $0,40 \%$ & $99,60 \%$ \\
\hline$-4,49$ & 3 & $-13,47$ & 61,94 & $0,64 \%$ & $99,36 \%$ \\
\hline$-3,89$ & 2 & $-7,78$ & 31,08 & $0,79 \%$ & $99,21 \%$ \\
\hline$-3,29$ & 15 & $-49,31$ & 167,32 & $1,99 \%$ & $98,01 \%$ \\
\hline$-2,69$ & 22 & $-59,08$ & 164,91 & $3,74 \%$ & $96,26 \%$ \\
\hline$-2,08$ & 31 & $-64,58$ & 141,41 & $6,20 \%$ & $93,80 \%$ \\
\hline$-1,48$ & 77 & $-114,06$ & 181,14 & $12,32 \%$ & $87,68 \%$ \\
\hline$-0,88$ & 134 & $-117,82$ & 116,33 & $22,97 \%$ & $77,03 \%$ \\
\hline$-0,28$ & 329 & $-91,21$ & 35,77 & $49,13 \%$ & $50,87 \%$ \\
\hline 0,32 & 334 & 108,48 & 24,77 & $75,68 \%$ & $24,32 \%$ \\
\hline 0,93 & 150 & 139,02 & 114,67 & $87,60 \%$ & $12,40 \%$ \\
\hline 1,53 & 71 & 108,55 & 154,75 & $93,24 \%$ & $6,76 \%$ \\
\hline 2,13 & 35 & 74,58 & 151,19 & $96,03 \%$ & $3,97 \%$ \\
\hline 2,73 & 19 & 51,93 & 136,51 & $97,54 \%$ & $2,46 \%$ \\
\hline 3,33 & 13 & 43,35 & 140,07 & $98,57 \%$ & $1,43 \%$ \\
\hline 3,94 & 7 & 27,56 & 105,62 & $99,13 \%$ & $0,87 \%$ \\
\hline 4,54 & 5 & 22,69 & 100,64 & $99,52 \%$ & $0,48 \%$ \\
\hline 5,14 & 2 & 10,28 & 51,79 & $99,68 \%$ & $0,32 \%$ \\
\hline 5,74 & 3 & 17,23 & 97,15 & $99,92 \%$ & $0,08 \%$ \\
\hline 6,35 & 0 & 0,00 & 0,00 & $99,92 \%$ & $0,08 \%$ \\
\hline 6,95 & 0 & 0,00 & 0,00 & $99,92 \%$ & $0,08 \%$ \\
\hline Укупно: & 1258 & 66,03 & $2.194,07$ & & \\
\hline \multicolumn{2}{|c|}{ Очекивана вредност } & $\overline{\boldsymbol{r}_{\boldsymbol{p}}}={ }_{0,05}$ & $\sigma 2=1,75$ & Варијанса & \\
\hline & & & $\sigma=1,32$ & $\begin{array}{c}\text { Ст. де- } \\
\text { вијација }\end{array}$ & \\
\hline
\end{tabular}

Извор: www.београдска берза, преглед

Израчуната је аритметичка средина расподеле и стандардна девијација применом наведених једначина, при чему је израчуната вредност аритме- 
тичке средине $\mathrm{p}=0,05$ идентична, а стандардна девијација $\sigma=1,32$ скоро идентична оној која се добија од негруписаних података. Хистограм сачињен на основу табеле има звонасти облик, са приближно симетричним распоредом око средње вредности, слично Гаусовој кривој:

Грабички приказ бр. 1 - Хистограм расподеле

\section{ХИСТОГРАМ}

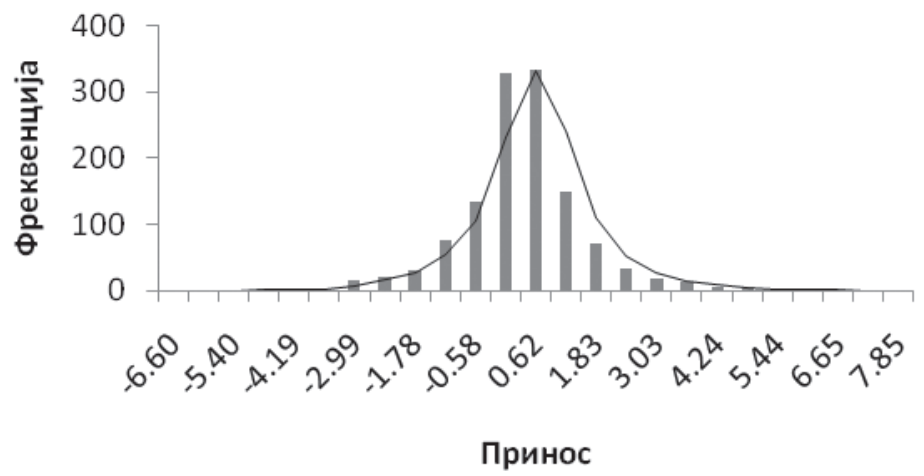

Извор: Риск гуард програм који користи Компанија Дунав

Вероватноћу а из претходног примера можемо унапред одредити, рецимо $\alpha=0,05=5 \%$, па користећи основни скуп података о кретању приносних стопа акција АИК банке, сортиран од најниже ка највишој стопи, као 63-опсервацију почевши од најниже $\left(1.258^{\star} 0,05^{\cong} 63\right.$ добијамо; $\mathrm{x} \alpha$ $0,05=-1,98 \%$

Износ вероватноће а називамо ниво толеранције, па, у овом случају кажемо да са толеранцијом од 5\% губитак не може прећи износ од 1,98\% од уложених средстава, односно да постоји свега 5\% вероватноће да ће стварни губитак следећег дана премашити наведени износ. Једнакост се може формулисати и на другачији начин имајући у виду да је

$$
\begin{aligned}
& \Pi\left(\mathrm{p}_{\mathrm{n}}<\mathrm{x}_{\alpha} \%\right)+\Pi\left(\mathrm{p}_{\mathrm{n}} \geq \mathrm{x}_{\alpha} \%\right)=1, \text { a да је } \\
& \Pi\left(\mathrm{p}_{\Pi}<\mathrm{x}_{\alpha} \%\right)=\alpha
\end{aligned}
$$

при чему ради конзистентности узмимо да је је х $\alpha=$ ц1- $\alpha$, тада је 


$$
\Pi\left(\mathrm{p}_{\mathrm{n}} \geq \mathrm{L}_{1-\alpha} \%\right)=1-\alpha
$$

Вероватноћу из претходне једнакости називамо ниво поверења. Дакле, користећи наш претходни пример, можемо рећи са поверењем које се мери вероватноћом од 95\% да губитак следећег дана неће премашити износ од 1,98\% од уложених средстава. Величина која се, на основу граничног параметра Ц $1-\alpha=-1,98$, добије за износ уложене суме C, назива ce VaR (Value at risk), односно вредност под ризиком:

$$
\operatorname{VaR}_{1-\alpha}=-\mathrm{Cц}_{1-\alpha}
$$

$\mathrm{VaR}$ je, дакле, губитак, који неће бити премашен, у одређеном временском периоду, уз унапред одређени степен вероватноће. Ако узмемо да је у претходном примеру вредност портфолиа 1.620.414,00 динара, односно да смо уложили у акције АИК банке и обвезнице А 2013 1.620.414,00 РСД, једнодневни VaR са нивоом поузданости од 95\%, износи VaR 0,95 = $-1.620 .414,00 *(-1,98 \%)=32.084,00$ РСД. што значи да током дана има само 5\% шансе да ће губитак следећег дана бити већи од 32.084,00 РСД, или, што је исто, постоји 95\% вероватноће да губитак следећег дана неће премашити поменути износ. VaR је мера ризика губитка због пада цена, изражена y новчаним јединицама (динарима) и представља максимални губитак у циљаном временском хоризонту са малом, унапред одређеном вероватноћом да ће стварни губитак бити већи (ниво толеранције)', односно са унапред одређеном довољном великом вероватноћом да стварни губитак неће бити већи (ниво поверења). VaR се израчунава са одређеним нивоом поверења, обично 95\% или 99\%, са основном идејом да процени могуће губитке под "нормалним" околностима.

$\mathrm{VaR}$ као мера ризика дефинисан је са два квантитативна параметра, нивоом поузданости и временским хоризонтом. Ако одредимо већи ниво поузданости, то подразумева да ће VaR, односно процењена вредност губитка бити већа - за ниво поверења од $99 \%$ вредност VaR je очигледно већа, него за ниво поверења од 95\%. У том случају

Ц $0,99=-3,55 \%$

па је

$9 * 1-\alpha=1-0,05=0,95=95 \%)$

** Знак минус ставља се испред израза да би износ губитка био изражен у позитивним бројевима (новчаним јединицама). 


\section{VaR 0,99 $=-1.620 .414,00(-3,55 \%)=57.525,00$ РСД}

За ниво поверења најчешће се узимају вероватноће од 99\% и 95\%. Уколико се процењује колики је капитал потребан да би се избегао ризик стечаја, наравно, узима се већа вероватноћа. Такође, за одређивање додатног капитала за покриће ризика, регулаторни органи траже конзервативније процене (99\%), док постављање лимита може засновано на нижим нивоима поверења (95\%). Пројекат Солвентност II за осигуравајуће компаније поставља захтев за мерење ризика са нивоом поверења од 99,5\%. Наравно, ниво поузданости се може повећавати на 99,9\%, 99,99\% и тако даље, чиме ће вредност VaR-a (могућег губитка) бити све већа, али и све мање вероватна, не узимајући у обзир техничке тешкоће израчунавања, ако је реч о временским серијама. Други битан фактор који утиче на вредност VaR-a је временски период (хоризонт), на који се VaR односи. Дужи временски период подразумева већу VaR меру - губитак који неће бити премашен, са унапред датим поверењем није исти за један дан и за 10 дана. Обрачунавањем стопе приноса за 10 -дневне инвестиционе периоде у претходном примеру кретања приноса од портфолиа акција АИК банке користећи основни скуп података о кретању приносних стопа акција АИК банке, сортиран од најниже ка највишој стопи, као 62-опсервацију почевши од најниже $\left(1.249^{*} 0,05 \cong 62\right)$ добијамо: х $0,05=-7,71 \%$

што значи да са толеранцијом од 5\% губитак не може прећи износ од $7,71 \%$ од уложених средстава, односно да постоји свега $5 \%$ вероватноће да ће стварни губитак у следећих 10 дана премашити наведени износ. Са вероватноћом (нивоом поверења) од 95\% можемо устврдити да губитак у следећих 10 дана неће премашити 7,71\% од уложених средстава, односно за уложених 1.620.414,00 РСД у акције десетодневни VaR се израчунава као

$$
\text { VaR 0,95(10 дана) }=-1.620 .414,00(-7,71 \%)=124.934,00 \text { РСД }
$$

Повећањем нивоа поверења на 99\% добијамо (као 63-опсервацију почевши од најниже $-1.249^{\star} 0,05 \cong 62$ ) ц $0,99=-12,66 \%$, односно за $1.620 .414,00$ РСД уложених средства са нивоом поверења од 99\% израчунава се десетодневни VaR као VaR 0,99 (10 дана) $=-1.620 .414,00(-12,66 \%)=205.144,00$ РСД. Очигледно да вредност VaR расте са повећањем временског хоризонта, али не пропорционално.

Маргинални VaR ( $\Delta \mathrm{VaR})$ показује за колико ће се динара променити укупни VaR уколико се у неку хартију уложи додатни мали новчани износ. Ако у нашем примеру портфолиа које чине акције АИК банке (200 акција) 
и обвезнице A2013 (100 обвезница) купимо додатну акцију АИК банке, тако да структура портфолиа буде 201 акција АИК банке и 100 обвезница A2013, вредност VaR за нови портфолио ће износити;

VaR 0,95 $=-1.623 .737,00$ РСД $(-1,99 \%)=32.312,00$ РСД

У том случају $\Delta$ VaR 0,95 $=32.312,00$ РСД - 32.084,00 РСД $=228$

Дакле, за додатно уложених 3.323 РСД (цена једне акције АИК банке), повећање вредности VaR ће износити 228,00 РСД, односно улагањем у акције АИК банке укупан ризик инвестиционог портфолиа ће се повећавати. Узмимо други случај - да додатно улагање извршимо у обвезнице А2013 куповином једне обвезнице по цени од 9.558,14 РСД тако да структура портфолиа буде 200 акција АИК банке и 101 обвезница А2013, вредност VaR за нови портфолио ће износити;

$$
\text { VaR 0,95 = -1.629.972,00 РСД* }(-1,97 \%)=32.110,00 \text { РСД }
$$

Тада је $\Delta \mathrm{vaR} 0,95=32.110,00$ РСД - 32.084,00 РСД = 26

За додатно уложених 9.558,14 РСД (цена једне обвезнице А2013), повећање вредности VaR ће износити 26,00 РСД, односно улагањем у обвезнице А2013 укупан ризик инвестиционог портфолиа ће се повећавати, али спорије него у првом случају (додатно улагање у акције АИК банке). Закључујемо да је мањи ризик улагати у обвезнице.

Компонентни VaR (ЦVaR) говори колики је допринос ризику сваке хартије у оквиру датог портфолиа и представља адитивну декомпозицију VaR-a која укључује ефекте диверсификације. Компонентни VaR говори колико би се $\mathrm{VaR}$ портфолиа променио уколико би се читава компонента искључила из портфолиа. При томе, треба имати у виду да ризик појединих инструмената није адитивна величина тј.:

$$
\sigma_{\pi \neq} \sigma_{1+} \sigma_{2+\ldots}
$$

Компонентни VaR се рачуна тако што се промена VaR-a, због искључења одређене позиције из портфолиа помножи са пондером позиције y укупном портфолиу и вредношћу портфолиа: $\quad$ ЦVaR $=\Delta V a R$ V.wи.C

ЦVaR може бити позитиван или негативан. Компоненте са негативним ЦVaR-ом ублажавају ризик портфолиа. ЦVaR зависи од ризичности дате компоненте и од њеног пондера у оквиру портфолиа. У нашем случају, 
уколико би из портфолиа искључили обвезнице А2013, ризик би се свео искључиво на акције АИК банке. Користећи основни скуп података о кретању приносних стопа акција АИК банке, сортиран од најниже ка највишој стопи, као 63-опсервацију почевши од најниже $\left(1.258^{\star} 0,05 \cong 63\right.$ ) добијамо $\mathrm{x} \alpha=0,05=-4,48 \%$ Пошто смо у претходном примеру уложили у куповину 200 акција АИК банке 664.600 РСД, једнодневни VaR са нивоом поузданости од 95\%, износи:

$\operatorname{VaR}($ АИКБ) $0,95=-664.600,00$ РСД * $(-4,48 \%)=29.774,00$ РСД

У том случају промена вредности једнодневног VaR-a када су искључене обвезнице износи 29.774,00 РСД. Пошто имамо само две позиције у портфолиу (акције АИК банке и обвезнице А2013) постоје две компоненте ризика, тако да ћемо у другом случају искључити позицију акција АИК банке.

ЦvaR (A2013) 0,95 = 9558,14 (вредност обвезнице) * 100 (број обвез. $)^{\star}(-1,26)=11.511,00$ РСД. Добијена вредност показује промену вредности једнодневног VaR-a кад су искључене акције АИК банке. Интерпретирајући ове податке можемо закључити да је ризик улагања у акције АИК банке значајно већи у односу на обвезнице А2013, јер искључивањем позиција обвезница из портфолиа, ризик је већи, а самим тим и потенцијални губитак (29.774,00 РСД) у односу на искључење акција (11.511,00 РСД).

Инкрементални VaR (ИVaR) означава колико ће се променити VaR портфолиа додавањем нове позиције (y): $И \mathrm{VaR}=\mathrm{VaR}+\mathrm{y}-\mathrm{VaR}$

или приближно: ИVaRи $\approx \Delta \mathrm{VaRuYи}$

Негативан ИVaR значи да ће додавање позиције смањити ризик (VaR), позитиван ИVaR значи да ће се додавањем позиције ризик повећати. Инкрементални VaR се рачуна за оне хартије које не постоје у портфолиу, a расположива је историја цена у бази података. Инкрементални VaR показује колико би се променио VaR уколико би се у инвестициони портфолио додала нова хартија од вредности, због чега је значајан за доношење одлуке о додатном инвестирању. Допринос ризику поједине трансакције рачуна се множењем инкременталног VaR-a ca бројем хартија који се укључује у портфолио. Користећи основни скуп података о кретању приносних стопа нашег портфолиа који се састоји од 200 акција АИК банке и 100 
обвезница А2013 и под претпоставком укључења једне акције фирме Соја Протеин, ${ }^{10}$ добијамо вредност VaR са нивоом поузданости од 95\%.

$$
\begin{aligned}
& \operatorname{VaR}(\text { АИКБ }+ \text { А2013+СЈПТ) } 0,95=-1.621 .264,00 \text { РСД* }(-1,99 \%)=32.263,00 \\
& \text { РСД }
\end{aligned}
$$

Користећи податак о вредности VaR без укључене акције Сoja Протеин (једнакост) добијамо;

$$
\text { ИVaR }=\operatorname{VaR}(\text { АИКБ }+ \text { A2013 + СЈПТ) 0,95 - VaR (АИКБ + А2013) 0,95 }
$$

$$
\text { ИvaR }=32.263,00 \text { РСД }-32.084,00 \text { РСД = 179,00 РСД }
$$

Улагањем у акцију Соја Протеин повећаће се вредност VaR за 179,00 РСД, што значи да ће се додатним улагањем у ове акције ризик портфолиа повећати. Куповином 100 акција Соја Протеин вредност VaR би се увећала за 17.900,00 РСД (179,00 РСД¹00). Маргинални, компонентни и инкрементални VaR имају велики значај за управљање ризиком инвестиционог портфолиа, односно за доношење одлука о куповини или продаји појединих хартија од вредности. Као што смо већ видели на практичном примеру сваки од ових показатеља има одређено значење - маргинални $\mathrm{VaR}$ се односи на утицај промена позиција које су већ укључене у портфолио, компонентни VaR говори о утицају искључења одређене позиције (хартије од вредности) на ризик портфолиа, док инкрементални VaR мери утицај укључења нове позиције (хартије од вредности) у инвестициони портфолио. Наравно, све резерве које се могу изразити на историјски VaR као меру ризика (извођење погрешних закључака у нестабилним тржишним условима или у случају неликвидности појединих позиција) важе и за маргинални, компонентни и инкрементални $\mathrm{VaR}$, због чега увек треба вршити и квалитативну анализу приликом доношења инвестиционих одлука. Квалитативна анализа сублимира читав спектар сазнања актуара, економиста, правника, математичара о посматраном инвестиционом ризику у реалном, садашњем времену. Квалитативна анализа не искључује значај и прорачун квантитативног модела (који је базиран на историјским подацима), већ само надопуњује исти садашњом релевантном оценом. Укрштају се подаци добијени са сајта Агенције за привредне регистре, сајта Народне банке Србије, сајта Београдске берзе, сајта Пореске управе и Министарства финансија, интерни подаци осигуравача и доноси коначан суд

10 Акције Соје протеин су изабране јер су биле ликвидне у посматраном периоду, тј. предмет трговине од 01.01.2006. до 31.12.2010. године (најмање 70\% времена или 881 дан). 
о посматраној инвестиционој одлуци. Тек након допуњене квантитативне оцене процене ризика инвестирања тj. VaR модела, са квалитативном оценом, односно експертском проценом базираном на актуелним информацијама о посматраном инвестиционом ризику, можемо бити сигурни да смо предузели све активности у циљу доношења најоптималније инвестиционе одлуке која подразумева максимизирање приноса уз прихватљив ниво ризика инвестирања.

\section{VAR АНАЛИЗА И ДОНОШЕЊЕ УПРАВЉАЧКИХ ОДЛУКА ВЕЗАНИХ ЗА ИНВЕСТИРАЊЕ СРЕДСТАВА}

$\mathrm{VaR}$ анализа има смисла уколико може да послужи као корисно средство за доношење управљачких одлука везаних за инвестирање средстава. При томе се одређене одлуке посматрају са становишта њиховог утицаја на укупни ризик. Нобеловац Harry Markowitz развио је систем управљања портфолиом који се заснива на комбиновању ризика и стопе приноса портфолиа у целини. Његова портфолио теорија је основа за доношење одлука од стране инвеститора у погледу одабира хартија од вредности које he caчињавати његов портфолио. За сваку хартију од вредности могу се предвидети различите могуће стопе приноса и вероватноће њиховог настанка. На основу расподеле вероватноћа могућих приноса може се утврдити очекивана вредност приноса. Очекивани принос се често не остварује, односно инвестирана средства доносе мањи принос од очекиваног, а у неким случајевима и губитак. Одступања од очекиване вредности статистички се могу мерити варијансом, односно стандардном девијацијом, која представља најприроднију меру ризика о чему је већ било речи. Што су већа могућа одступања од очекиване вредности и што је већа њихова вероватноћа, вредност варијансе је већа, односно већи је ризик инвестирања. Диверсификација представља кључни фактор за смањивање укупног ризика портфолиа. Ефекат диверсификације настаје због тога што различите хартије од вредности имају различите вероватноће наступања одређених исхода у погледу приносних стопа, због чега опадање стопе приноса једне хартије од вредности може бити праћено растом приносне стопе друге хартије од вредности. У овом случају постоји негативна корелација између кретања приносне стопе две хартије од вредности, која поништава позитивне и негативне ефекте у кретању њихових приносних стопа, односно смањује укупни ризик портфолиа. По Markowitz-u за инвеститора није у тој мери важно да ли приносне стопе појединачних хартија од вредности расту или падају, него какав је однос приноса и ризика за укупни портфолио хартија од вредности. Сваким додатним улагањем у нове хартије од вредности би 
се у принципу смањивао ризик изражен у вредности VaR-a, све док диверсификацијом ризик не би био сведен на систематски (тржишни), који у подједнакој мери утиче на већину хартија од вредности на финансијском тржишту. Улагањем у нову хартију од вредности може се постићи тзв. бенефит од диверсификације. На финансијским тржиштима се генерално сматра да је разноврснији портфолио средстава мање ризичан него недиверсификован портфолио. У нашем случају улагања у акције АИК банке (200 акције) и обвезнице A 2013 (100 обвезница) бенефит од диверсификације уз коришћење једнодневног VaR-a са нивоом поузданости 95\% би се могао израчунати на следећи начин:

Бенефит $(\operatorname{VaR} 0,95)=(200 \times 3323,00 \times 4,48 \%+100 \times 9.558,14 \times 1,26 \%)-$ $(200 \times 3323,00+100 \times 9.558,14) \times 1,98 \%$

Односно, Бенефит $(\mathrm{VaR} 0,95)=9.733,14$ РСД

Претходна калкулација говори да ће се највећи једнодневни губитак са нивоом поузданости од 95\% формирањем портфолиа од две хартије смањити за 9.733,14 РСД или за око 23,3\% у односу на потенцијални губитак у случају улагања у појединачне хартије од вредности (акције АИК банке и обвезнице А2013). Наравно ова анализа не говори о другој страни медаље, односно о приносима. Преузимање већег ризика, као када је реч о потенцијалном губитку, може у истој мери значити и могућност остварења веће добити. Однос између очекиваног приноса и потенцијалног губитка због ризика улагања је срж и најбитнија карика у доношењу управљачких одлука везаних за инвестирање средстава на финансијском тржишту. Оптимизација односа између приноса и ризика предмет је врло сложених теоријских модела. Представићемо један релативно једноставан модел који на пластичан начин указује на технологију доношења управљачких одлука код инвестирања средстава. Приказаћемо прорачун ризика на тржишту капитала Београдске берзе две компаније које су на листингу А и као такве представљају сигуран пласман за осигуравајућа друштва. Чињеница је да је вредност листираних акција малог обима и да су осигуравајућа друштва, укључујући и Компанију Дунав вршила пласмане код других емитера ван листинга А. Један од разлога је тај што су техничке резерве као главни извор пласмана биле недовољне да се на дужи рок та средства на овај начин имобилишу. Осигуравајућа друштва су вршила сигурније пласмане депоновањем код пословних банака на кратак рок и пласманом у хартије од вредности код Народне банке Србије. Наш пример треба да послужи само као приказ једног од модела како су осигуравајућа друштва могла да диверсификују свој портфолио у сигурне пласмане на тржишту капитала. Надовезујући се на претходни пример претпоставимо да смо уложили 
целокупан износ од 1.620.414,00 РСД само у акције АИК банке. Очекивани дневни принос, на бази историјског сценарија од 1258 опсервација (период од 01.01.2006. године до 31.12.2010. године), износи: РСД

$\mathrm{E}\left(\right.$ рп $_{\text {п }}$ АИКБ $=1.620 .414,00$ х 0,06\% (просечна стопа приноса) $=972,25$

Потенцијални максимални једнодневни губитак, са нивоом поверења од 95\% (VaR), у овом случају износи: $\mathrm{VaR}$ 0,95 (АИКБ) $=1.620 .414,00$ х 4,48\% $=72.594,55$ РСД

Однос између једнодневног очекиваног приноса и највећег потенцијалног губитка може се изразити коефицијентом;

$$
\frac{\mathrm{E}\left(r_{p}\right)_{\text {АИКБ }}}{V a R_{0,95}(\text { АИКБ })}=\frac{972,25}{72.594,55}=0,01339
$$

У овом случају мера ризика није варијанса, односно стандардна девијација, него вредност $\mathrm{VaR}$, која представља само негативну страну одступања од очекиване вредности. У случају да смо уложили $1.620 .414,00$ PCД само у обвезнице A2013 очекивани дневни принос и једнодневни VaR са нивоом поверења од 95\%, на бази историјског сценарија од 1258 опсервација (период од 01.01.2006. године до 31.12.2010. године), износе: Е (рп) А $2013=1.620 .414,00 \times 0,04 \%=648,17$ РСД

$$
\operatorname{VaR} 0,95(\mathrm{~A} 2013)=1.620 .414,00 \times 1,26 \%=20.417,22 \text { РСД }
$$

у ком случају коефицијент односа између једнодневног очекиваног приноса и највећег потенцијалног губитка са нивоом поверења од 95\% износи:

$$
\frac{E\left(p_{\pi}\right)_{A 2013}}{\operatorname{VaR}_{0,95}(A 2013)}=\frac{648,17}{20.417,22}=0,03175
$$

У трећем случају улагања 1.620.414,00 РСД у портфолио који се састоји од 200 акција АИК банке и 100 обвезница А2013 очекивани дневни принос и једнодневни $\mathrm{VaR}$ са нивоом поверења од 95\% износе:

$\mathrm{E}\left(\mathrm{p}_{\text {п) }}\right.$ Портфолио $=1.620 .414,00 \times$ x 0,05\% $=810,21$ РСД

VaR $0,95=1.620 .414,00 \times 1,98 \%=32.084,20$ РСД 
Коефицијент којим се мери однос између очекиваног дневног приноса портфолиа и највећег потенцијалног губитка са нивоом поверења од 95\% износи 0,02525 :

$$
\frac{\mathrm{E}\left(\mathrm{p}_{\mathrm{n}}\right) \text { Портфолио }}{\left.\operatorname{VaR}_{0,95} \text { (Портфолио }\right)}=\frac{810,21}{32084,20}=0,02525
$$

Из приказане калкулације јасно се може видети да би најповољнији однос између приноса и ризика био остварен улагањем само у обвезнице старе девизне штедње А2013 (коефицијент 0,03175), а најнеповољнији улагањем само у акције АИК банке (коефицијент 0,01339). Наравно, ова анализа полази од претпоставке да на очекивани дневни принос и једнодневни VaR подједнако утичу све дневне опсервације у петогодишњем периоду, са циљем да се потенцира однос између приноса и ризика као најбитнијег фактора при доношењу управљачких инвестиционих одлука. Ова анализа се може проширити и на деривације VaR анализе - маргинални, компонентни и инкрементални VaR. Горе наведена анализа показује да се искључењем позиције АИК банке из портфолиа (компонентни VaR) и улагањем целог износа у обвезнице побољшава однос између очекиваног дневног приноса и једнодневног VaR са нивоом поверења од 95\%. Међутим, у случају искључења позиције обвезнице А2013 и улагањем целог износа у акције АИК банке ефекат изражен односом између очекиваног дневног приноса и $\mathrm{VaR}$ постаје неповољнији. Једнодневни VaR у случају додатног улагања у једну акцију АИК банке (маргинални VaR), уз ниво поверења од $95 \%$ и укупан износ улагања од 1.623.737,00 РСД $(1.620 .414+3.323)$ износи:

$$
\text { VaR } 0,95=1.623 .737,00 \times 1,99=32.312,00 \text { РСД }
$$

Очигледно, додатним улагањем у једну акцију АИК банке укупан ризик портфолиа ће се повећати за 227,8 РСД (разлика између 32.084,20 и $32.312,00)$. Такође је очигледно да ће се додатним улагањем у акције АИК банке погоршати однос између очекиваног дневног приноса и износа једнодневног VaR-a:

$$
\begin{aligned}
& \mathrm{E}\left(\mathrm{p}_{\pi}\right)=1.623 .737 \times 0,05 \%=811,87 \text { РСД } \\
& \frac{\mathrm{E}\left(\mathrm{p}_{\pi}\right)}{\operatorname{VaR}_{0,95}(\text { Марг. Акције })}=\frac{811,87}{32312,37}=0,025125
\end{aligned}
$$

Коефицијент којим се мери однос између очекиваног дневног приноса и $\mathrm{VaR}$ у овом случају износи 0,02512 и нешто је неповољнији него пре 
додавања једне акције у портфолио који се састоји од 200 акција АИК банке и 100 обвезница А 2013 (0,02525). Ово значи да се додатним улагањем у акције АИК банке однос између очекиваног дневног приноса и износа $\mathrm{VaR}$ погоршава. Ако уложимо додатни износ (1.629.972,00 РСД = 1.620.414 + $9.558,14)$ у једну обвезницу А 2013 очекивани дневни принос и једнодневни VaR портфолиа са нивоом поверења од 95\% ће износити:

$$
\begin{aligned}
& \mathrm{E}\left(\mathrm{p}_{\pi}\right)=1.629 .972 \times 0,05 \%=814,99 \text { РСД } \\
& \operatorname{VaR} 0,95=1.629 .972,00 \times 1,97 \%=32.110,45 \text { РСД } \\
& \frac{\mathrm{E}\left(\mathrm{p}_{\pi}\right)}{\operatorname{VaR}_{0,95}(\text { Марг. Обвезнице })}=\frac{814,99}{32110,45}=0,02538
\end{aligned}
$$

Однос између очекиваног дневног приноса и VaR у овом случају износи 0,02538 што је повољније него пре додавања једне акције у портфолио који се састоји од 200 акција АИК банке и 100 обвезница А2013 (0,02525). У нашем случају уколико би се у портфолио додала нова позиција, акција Соја Протеин (инкрементални VaR), при вредности портфолиа од 1.621.264,00 РСД (1.620.414 + 850 - вредност акције Соје Протеин на дан 31.12.2010. године) и износу $\mathrm{VaR}$ од 32.263,00 РСД, очекивана вредност дневног приноса je:

$\mathrm{E}\left(\mathrm{p}_{\pi}\right)=1.621 .264,00 \times 0,05 \%=810,63$ РСД

$\operatorname{VaR} 0,95=1.621 .264,00 \times 1,99 \%=32.263,00$ РСД

a однос између добити и VaR за нови портфолио је:

$$
\frac{E\left(p_{n}\right)}{\operatorname{VaR}_{0,95}}=\frac{810,63}{32 \cdot 263,00}=0,02513
$$

што значи да се додатним улагањем у акције Соја Протеин у портфолио који се састоји од 200 акција АИК банке и 100 обвезница А2013 однос између очекиване дневне добити и једнодневног VaR погоршао, што још једном потврђује закључак из анализе инкременталног VaR да ће се додатним улагањем у акције Соја Протеин ризик портфолиа повећати, и то брже него што ће расти очекивани принос. Из свега наведеног можемо закључити да je најповољнији однос између приноса и ризика код Маргиналног VaR-a A2013, односно додатног инвестирања у обвезнице старе девизне штедње када је израчунати коефицијент и највећи 0,02538. Уколико наведеном прорачуну додамо и анализу инвестиционог портфолиа Сектора оси- 
гурања у Србији (Графички приказ бр. 2) и анализу инвестиционог портфолиа осигуравача у Европској унији (Графички приказ бр. 3) видимо да су у нашој земљи доминантна улагања у државне хартије од вредности (већину чине обвезнице старе девизне штедње), депозите код банака и готовину, док је у Европској унији, пре свега, заступљено улагање у корпоративне обвезнице због највиших приноса. У нашој земљи тај вид улагања је још увек симболичан.

Графички приказ бр. 2 - Структура улагаюа осигуравача у Србији у 2012. години

\section{Структура инвестиционог портфолиа осигуравача у Србији у 2012. години}

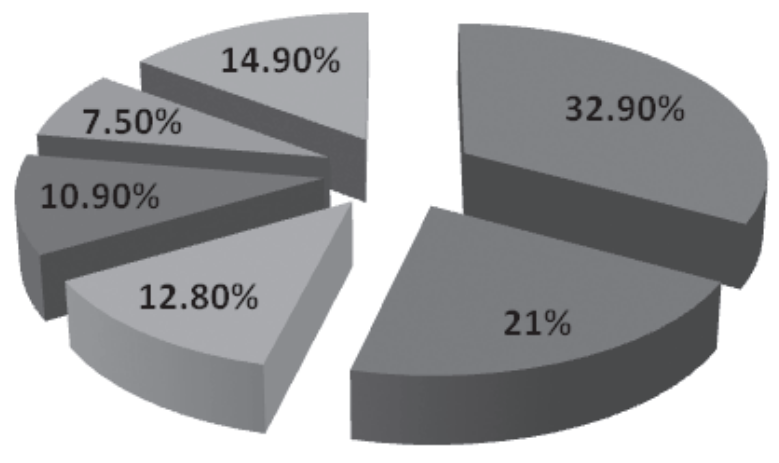

- Државне Хов

- Депозити код банака

готовина

Некретнине

- Потраживањаза недоспеле премије - Остало

Извор: www.нбс.рс, Сектор осигураға у Србији у 2012. години 
Графички приказ бр. 3 - Структура улагаюа осигуравача у Европској унији y 2012. год.

\section{Структура инвестиционог портфолиа осигуравача у ЕУ у 2012. год.}

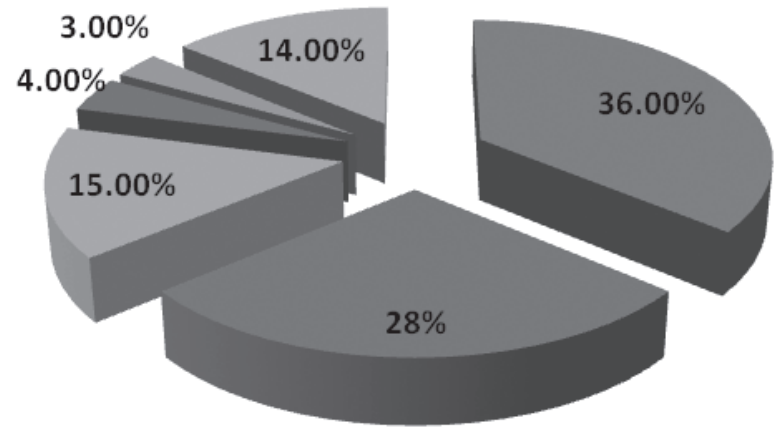

Корпоративне

обвезнице

- Државне Хов

пкције

口 Некретнине

п Готовина

Остало

Извор: Инсуранце Еуропе

Доказ неразвијености и банкоцентричности финансијског тржишта у нашој земљи пружа и наредни графички приказ кроз пресек учешћа актера финансијског система у билансној суми у 2012. години.

Грабички приказ бр. 4 - Финансијски систем Србије према учешћу у билансној суми у 2012. години

\section{Финансијски систем Србије према учешћу у билансној суми у 2012. години}

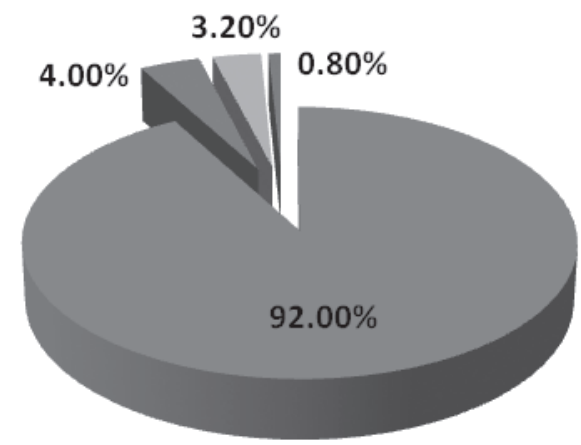

Банке

п Друштва за осигурање

Лизинг друштва

- Остали

Извор: www.апр.гов.рс, Агенција за привредне регистре, Годишюи извештај.

11 Funding the future, Insurers role as institutional investors (Улога осигуравача као институционалних инвеститора), jun 2013., str. 19. 
Сублимирајући наведено, кроз приказани квантитативни VaR модел и коефицијент приноса, графички приказ структуре инвестиционог портфолиа у Србији и земљама Европске уније, као и графички приказ банкоцентричности нашег финансијског система (Графички приказ бр. 4), долазимо до закључка да неразвијеност финансијског тржишта у нашој земљи, као и банкоцентричност истог, увелико ограничава и спутава оптимизацију депоновања и улагања слободних финансијских средстава осигуравача и фаворизује конзервативан начин улагања у обвезнице старе девизне штедње и депозите. Код процеса доношења управљачких инвестиционих одлука контрола ризичности се може вршити и на начин да се свакодневно проверава да ли су обрачунате вредности VaR-a у оквиру квантитативно дефинисаних лимита. Одговарајућим актом (Политикама управљања ризицима или прописима које диктира Надзорни орган) може се утврдити вредност ризика (VaR-a) која сигнализира/упозорава да је преузети ризик близу максимално прихватљивог. Нпр. може се дефинисати да лимит за укупан ризик портфолиа изражен вредношћу VaR (максимално могући губитак вредности имовине) са нивоом поверења од 99\% у следећих 10 дана износи 5\% од укупне вредности портфолиа, при чему би ниво вредности VaR који би представљао сигнал, односно упозорење за промене у политици инвестирања, требало да буде постављен на нижем нивоу, нпр. да износи 3,8\% од вредности портфолиа. Тиме би се одговарајуће корективне активности могле спровести пре него што буде достигнут утврђени лимит. Овакав начин процене ризика је посебно пријемчив за пензионе фондове.

\section{ЗАКЉУЧАК}

Један од најпоузданијих алата за мерење тржишног ризика и доношење инвестиционих одлука где пласирати слободна финансијска средства јесте VaR (Value-at-Risk) модел базиран на историјским подацима. Његовом применом и израчунавањем Маргиналног, Компонентног и Инкременталног VaR-a врши се оптимизација портфолио инвестирања на финансијском тржишту. Маргинални, компонентни и инкрементални VaR имају велики значај за управљање ризиком инвестиционог портфолиа, односно за доношење одлука о куповини или продаји појединих хартија од вредности.

Сваки од ових показатеља има одређено значење - маргинални VaR се односи на утицај промена позиција које су већ укључене у портфолио, компонентни VaR говори о утицају искључења одређене позиције (хартије од вредности) на ризик портфолиа, док инкрементални VaR мери утицај 
укључења нове позиције (хартије од вредности) у инвестициони портрфолио. Све резерве које се могу изразити за историјски VaR као меру ризика (извођење погрешних закључака у нестабилним тржишним условима или у случају неликвидности појединих позиција) важе и за маргинални, компонентни и инкрементални $\mathrm{VaR}$, због чега увек треба вршити и квалитативну анализу приликом доношења инвестиционих одлука. Иста подразумева допуну квантитативних метода квалитативном оценом од стране портфолио менаџера.

Квалитативна анализа је базирана на садашњим, реалним подацима и сублимира читав спектар сазнања актуара, економиста, правника, математичара о посматраном инвестиционом ризику. Тек након допуњене квантитативне оцене процене ризика инвестирања тj. VaR модела који се заснива на историјским подацима који веома често нису валидна основа за предвиђање кретања у будућности, са квалитативном оценом, можемо бити сигурни да смо предузели све активности у циљу минимизирања ризика инвестирања.

Анализирајући структуру инвестиционог портфолиа у земљама Европске уније као и у нашој земљи, као и банкоцентричност домаћег финансијског система долазимо до закључка да је финансијско тржиште у Србији још увек недовољно развијено. Као такво, оно увелико ограничава и спутава оптимизацију депоновања и улагања слободних финансијских средстава осигуравача и фаворизује конзервативан начин улагања у обвезнице старе девизне штедње и депозите.

\section{SUMMARY \\ MARKET RISK AND VAR MODEL IN INVESTMENT OF FUNDS OF INSURANCE COMPANIES}

The growth in real gross domestic product and economic recovery of Serbia, despite being slowed down, is nevertheless bound to happen. This will also produce positive effects on the insurance sector in the Republic of Serbia which, in 2014, was worth 574 million Euros, showing an upwards trend. Naturally, an average premium will go up in non-life and especially in life business. This will create more room for investment activities, whereas the market position and survival of insurance companies will depend on their successful optimisation of deposits and investments of free financial funds in the financial market. When acting as players in the financial market, insurers primarily encounter market 
risk. One of the best tools for the management of such risk is the application of VaR model or Value-at-Risk model. Market risk management through VaR model is carried out in portfolio investment and represents maximum possible loss which will not be exceeded in a given period and for a given confidence interval. VaR model will be affirmed through a practical example of calculating Marginal, Incremental and Component $\mathrm{VaR}$, and its value lies in the fact that it enables the comparison of riskiness of different financial instruments and portfolios. The focus will be placed on the quantitative method used in management decisions related to investments of insurance companies and on the necessity to acknowledge the results of quantitative analysis.

Key words: market risk, VaR model, Marginal, Component and Incremental VaR, portfolio investment, quantitative and qualitative analysis...

\section{ЛИТЕРАТУРА:}

1. Барјактаровић, Л., Јечменица, Д., Управљағье ризиком у српским осигуравајућим

2. компанијама, Сингидунум ревија, Београд, 2010.

3. Богојевић-Арсић, В., Примена савремене портфолио теорије на доночене инвестииионих одлука, Сумопис, Београд, 1999.

4. Божић, Р., Инвестираюе у хартије од вредности и перспективе развоја финансијског тржичта у транзиционим економијама, Acta Economiса, Београд, 2003.

5. Dowd, K., Beyond value at risk: The new science of risk management, John Wiley\&Sons Ltd, West Sussex, England, 1998, стр. 39.

6. Elton, E., Gruber, M., Modern portfolio Theory and Investment Analysis (Модерна портфолио теорија и инвестициона анализа), John Wiley\&Sons Inc. United States of America, 2001, стр. 59.

7. Илић, Ј., Инвестииионе одлуке малих инвеститора, Пословна политика, Београд, 2007.

8. Јанковић, Д., Управљатье трошковима осигуравајућих компанија у условима нелојалне конкуренције, Међународни симпозијум УОС и Института за осигурање и актуарство, Златибор, 2010.

9. Јеремић, Љ., Пауновић, М., Компаративна анализа тржишта осигурағь у Европској унији, Србији и државама региона, Сингидунум ревија, Београд, 2011.

10. Јеремић 3., Проблеми дугорочног пласмана средстава осигуравајућих компанија и пензионих бондова у Србији, Други међународни симпозијум „Осигурање на прекретници“, Економски факултет у Београду и Удружење актуара Србије, 2004. 
11. Jorrion Phillipe, Value at Risk: The New Benchmark for Controlling Market Risk, Mc Graw-Hill, 2001, стр. 263

12. Панић, П., Управљағье ризиком инвестиционог портфолија осигуравајућих компанија, Надзор и контрола пословаюа осигуравајућих компанија, IX Међународни научни симпозијум, Економски факултет у Београду и Удружење актуара Србије, 2011.

13. Урошевић, Б., Value at Risk, Економски факултет Београд, Београд, 2008.

14. Цветковић Н., Алтернативне стратегије портфолио инвестирана, Финансије, бр. 9-10, 1998, стр. 730.

15. Center for Investments and Finance, Annual report, Центар за инвестиције и финансије, годищғи извештај, 2009, стр.52. 
